\title{
Sap Flow in Aleppo Pine in Greece in Relation to Sapwood Radial Gradient, Temporal and Climatic Variability
}

\author{
Evangelia Korakaki $^{1}$ (D) and Mariangela N. Fotelli ${ }^{2, *(\mathbb{D})}$ \\ 1 Institute of Mediterranean and Forest Ecosystems, Hellenic Agricultural Organization Demeter, P. O. Box \\ 14180, Terma Alkmanos, Ilisia, 11528 Athens, Greece; e.korakaki@fria.gr \\ 2 Forest Research Institute, Hellenic Agricultural Organization Demeter, Vassilika, 57006 Thessaloniki, Greece \\ * Correspondence: fotelli@fri.gr; Tel.: +30-2310-461172 (ext. 238)
}

check for

updates

Citation: Korakaki, E.; Fotelli, M.N. Sap Flow in Aleppo Pine in Greece in Relation to Sapwood Radial Gradient, Temporal and Climatic Variability. Forests 2021, 12, 2. https:/ / dx.doi.org/10.3390/f12010002

Received: 23 November 2020 Accepted: 18 December 2020 Published: 22 December 2020

Publisher's Note: MDPI stays neutral with regard to jurisdictional claims in published maps and institutional affiliations.

Copyright: () 2020 by the authors. Licensee MDPI, Basel, Switzerland. This article is an open access article distributed under the terms and conditions of the Creative Commons Attribution (CC BY) license (https: / / creativecommons.org/ licenses/by/4.0/).

\begin{abstract}
Research Highlights: The radial gradient of sap flux density (Js) and the effects of climatic factors on sap flow of Aleppo pine were assessed at different time scales in an eastern Mediterranean ecosystem to improve our understanding of the species water balance. Background and Objectives: Aleppo pine's sap flow radial profile and responses to environmental parameters in the eastern Mediterranean were, to our best knowledge, originating to date from more arid planted forests. Information from natural forests in this region was lacking. Our objectives were to (a) determine the species' radial variability in Js on a diurnal and seasonal basis and under different climatic conditions, (b) scale up to tree sap flow taking into account the radial profile of Js and (c) determine the responses of Aleppo pine's sap flow over the year to climatic variability. Materials and Methods: Js was monitored in Aleppo pine in a natural forest in northern Greece with Granier's method using sensors at three sapwood depths $(21,51$, and $81 \mathrm{~mm})$ during two periods differing in climatic conditions, particularly in soil water availability. Results: Js was the highest at $21 \mathrm{~mm}$ sapwood depth, and it declined with increasing depth. A steeper gradient of Js in deep sapwood was observed under drier conditions. The same patterns of radial variability in Js were maintained throughout the year, but the contribution of inner sapwood to sap flow was the highest in autumn when the lower seasonal Js was recorded in both study periods. Not taking into account the radial gradient of Js in the studied Aleppo pine would result in a c. 20.2-27.7 \% overestimation of total sap flow on a sapwood basis (Qs), irrespective of climatic conditions. On a diurnal and seasonal basis, VPD was the strongest determinant of sap flux density, while at a larger temporal scale, the effect of soil water content was evident. At SWC $>20 \%$ sap flow responded positively to increasing solar radiation and VPD, indicating the decisive role of water availability in the studied region. Moreover, in drier days with VPD $>0.7 \mathrm{KPa}$, SWC controlled the variation of sap flow. Conclusions: There is a considerable radial variability in Js of the studied Aleppo pine and a considerable fluctuation of sap flow with environmental dynamics that should be taken into account when addressing the species water balance.
\end{abstract}

Keywords: sap flux; radial profile; sapwood depth; Aleppo pine; diurnal variation; seasonal variation; climate

\section{Introduction}

Sap flux density and sap flow measurements are widely used in ecophysiological studies to investigate aspects of plant-water interactions such as canopy conductance [1-5], whole-plant hydraulic conductance [3,6], and leaf stomatal conductance [3,6-9]. To estimate these variables from sap flow monitoring, sap flux density (Js) measurements need to be upscaled to the tree level. In several studies [10-17], sap flow is estimated from sap flux density measurements with sensors installed in the outer part of the xylem, assuming uniform sap flux density across the sapwood. Berdanier et al. [18] reported that out of 122 reviewed articles (published between 2013 and 2015) that scaled 
up sap flux observations to whole-tree or stand levels, $58 \%$ assumed homogenous flow throughout the xylem.

However, neglecting radial variability may lead to systematic errors in the total sap flow [19-25]. Cermak and Nadezhdina [20] showed that upscaling sap flux density, measured in the outer half of the sapwood of different species, led to overestimation of total tree sap flow (by 10-140\%), whereas when measured in deep inner sapwood layers, total tree sap flow was underestimated (by 40-80\%). Similarly, Delzon et al. [22] showed that ignoring the variability in radial profile of sap flow in maritime pine trees led to an overestimation of transpiration and stand water use that increased with increasing stem diameter from $5 \%$ for the young stands to $47 \%$ for the oldest stands. To overcome these uncertainties, the radial variability in sap flux density in different trees has been determined $[19,26-30]$ or correction factors accounting for the spatial variation of sap flow with increasing sapwood radius have been developed [23,31]. Therefore, taking into consideration radial variability is highly important when upscaling sap flux density measurements to accurately estimate tree and stand level water balance, particularly for tracheid-bearing conifers that tend to have deep functional sapwood [18,32].

Variation in the sap flux radial profile in conifer stems, as well as variation in sap flow on the tree level, may be associated with time-dependent changes in environmental conditions. A number of studies have reported that changes in radial patterns were related to environmental variables, such as vapor pressure deficit and soil water availability. Phillips et al. [33] indicated that nighttime recharge of stem water storage increased with increasing soil moisture depletion. Čermak and Nadezhdina [20] showed that, under long-term drought, deeper layers of the sapwood contributed more to water transport. Similarly, Ford et al. [27] found that the radial profile of sap flux density was related to daily changes in evaporative demand, and that during periods of high transpiration, the inner xylem contributed more to total tree sap flow. Hernandez-Santana et al. [34] observed that Js increased at all explored xylem depths with increasing VPD from 8:00 to 11:00 GMT, but with higher VPD (till 15:00 GMT), Js continued increasing only in the deepest xylem, whereas the outer one decreased. In the study of Sanchez-Costa et al. [31], P. halepensis showed higher sensitivity of Js to VPD, than the rest diffuse-porous species examined and a higher soil moisture threshold for Js reductions, consistent with the species strict stomatal control under drought. Finally, Cohen et al. [35] supported that the depth of conducting sapwood in P. halepensis trees was larger in trees growing under a semi-arid climate than under a sub-humid climate. Thus, assessment of the climatic controls in different time scales on sap flow patterns is important in our effort to understand and predict Aleppo pine's responses to climate variability.

Aleppo pine is widely distributed in coastal and low elevation areas of the Mediterranean basin [36,37], being predominately threatened by the prevailing climate change [38], particularly at its eastern limits [39]. Thus, assessing this species' water balance in relation to environmental factors is crucial. Still, to our knowledge, limited information is available about the radial patterns of sap flux and its seasonal and diurnal fluctuation, in relation to climate, in P. halepensis at eastern Mediterranean ecosystems. Mostly, if not solely, the relevant literature refers to Aleppo pine plantations in Israel, such as the works of Schiller and Cohen [40] who first reported on the radial profile of sap flux in this species and Cohen et al. [35] who studied the radial sap flux gradients of Aleppo pines under different climatic conditions.

In the present study, we assessed the diurnal and seasonal variability of the radial profile of sap flux density of a mature near-coastal Aleppo pine ecosystem in Chalkidiki, northern Greece. We measured sap flux density in three sapwood depths $(21,51$ and $81 \mathrm{~mm})$ to take into account the radial variability of sap flux of Aleppo pine trees in estimating total sap flow and to explore its response to different temporal scales and to climatic variability. Given that high temporal variations in the sap flux density radial profile may be observed (e.g., [26]), monitoring was conducted during two periods (July 2008-November 2009 
and April 2019-April 2020) differing in climatic conditions and predominantly in water availability.

Our specific aims were to: (a) determine the radial profile of Js in Aleppo pine and explore its changes at a diurnal and seasonal scale during two periods differing in climatic conditions, (b) scale up to tree sap flow based on the radial variability of Js and quantify errors that occur when single-depth Js is scaled up to tree level and (c) assess the responses of Aleppo pine sap flow over the year to climatic variability.

\section{Materials and Methods}

\subsection{Description of Study Site and Data Collection}

The study was conducted in a natural Aleppo pine (Pinus halepensis Mill.) stand located at the Stavronikita forest, Chalkidiki, Northern Greece (latitude: $40^{\circ} 06^{\prime} \mathrm{N}$, longitude: $23^{\circ} 18^{\prime} \mathrm{E}$ ). The Aleppo pine stand grows at an elevation of $15 \mathrm{~m}$ above the sea level, has a mean slope $1 \%$ and is located at about $300 \mathrm{~m}$ distance from the coast. The understorey consists of a maquis shrub vegetation, dominated with Pistacia lentiscus L., Phyllirea media L. and Quercus coccifera $\mathrm{L}$. The soil has a high $\mathrm{pH}(7.5-8.2)$ and lies at the boundary between Calcari-chromic Vertisols and Chromic Luvisols. For the period 2008-2019, mean, minimum and maximum air temperatures were $16.3^{\circ} \mathrm{C}, 30.3^{\circ} \mathrm{C}$, and $3.5^{\circ} \mathrm{C}$, respectively, while mean annual rainfall was $604.8 \mathrm{~mm}$. A xerothermic season occurred from June till September.

Data were collected during two periods differing in soil water content and other climatic conditions, in order to determine variations in sap flow parameters (sap flux radial gradient-Js and sap flow per sapwood area -Qs) under different climatic conditions. The first recording period was from 1 July 2008 to 30 November 2009 and it was characterized by lower soil water content (hereafter called "dry period"), while the second period lasted from 13 April 2018 to 12 April 2020 and was characterized by higher soil water content (hereafter called "wet period").

\subsection{Micrometeorological Parameters}

Micrometeorological data were continuously recorded at a fully automated weather station operating at a c. $50 \mathrm{~m}$ distance from the forest stand. The recorded parameters included air temperature and air relative humidity at $5 \mathrm{~m}$ height (RHT2nl, Delta-T Devices Ltd., Cambridge, UK), solar radiation (SKS1110, Skye Instruments, Llandrindod Wells, UK), wind speed (model 4.3515.30.000, THIES CLIMA, Göttingen, Germany), wind direction (WD4, Delta-T Devices Ltd., Cambridge, UK), precipitation (AR100 and RGB1, EML, North Shields, UK), and soil water content at a $30 \mathrm{~cm}$ depth (ML2X/W, Delta-T Devices Ltd., Cambridge, UK). All values were data-logged (DL2e Delta-T Logger, Delta-T Devices Ltd., Cambridge, UK) at 60-min and 30-min intervals during the 1st and the 2nd period, respectively. Vapor pressure deficit (VPD) was also calculated on a 60-min and 30-min basis from relative humidity and air temperature data.

\subsection{Biometric Traits of Selected Trees and Sapwood Area Determination}

The mean Aleppo pine tree density at the study site is c. 130 trees/ha. The majority of the trees (c. $85 \%$ ) have a DBH $>30 \mathrm{~cm}$. In order to measure the sap flux of trees that are representative of the studied forest, individuals with DBH lower than this threshold were excluded, while attention was paid to selecting non-neighboring, dominant Aleppo pines. The biometric traits of the selected Aleppo pines are given in Table 1. DBH and sapwood depth were measured during both study periods, while tree height and canopy projected area were determined only during the 2nd (wet) period. For the determination of canopy projected area, the radius of the crown's orthogonal projection was measured at four directions (north, south, east, and west) to build an average radius per tree. One Aleppo pine tree (Pine 4 ) has been harvested after the 1st (dry) period and has been replaced by another one with similar DBH and height, before the initiation of the 2nd period, as indicated in Table 1. 
Table 1. Biometric traits of the monitored Aleppo pine trees.

\begin{tabular}{|c|c|c|c|c|c|c|}
\hline \multirow[t]{2}{*}{ Pine } & \multicolumn{2}{|c|}{ DBH (cm) } & \multicolumn{2}{|c|}{ Sapwood Radius (cm) } & \multirow{2}{*}{$\begin{array}{l}\text { Height } \\
\text { (m) }\end{array}$} & \multirow{2}{*}{$\begin{array}{c}\text { Canopy } \\
\text { Projected } \\
\text { Area }\left(\mathrm{m}^{2}\right)\end{array}$} \\
\hline & 1st period & 2nd period & 1st period & 2nd period & & \\
\hline 1 & 56.3 & 57.1 & 25.0 & 25.3 & 19.4 & 100.3 \\
\hline 2 & 43.9 & 45.8 & 19.7 & 20.5 & 17.4 & 48.4 \\
\hline 3 & 33.7 & 37.1 & 15.3 & 16.8 & 14.9 & 40.2 \\
\hline $4^{(1)}$ & 30.6 & 34.1 & 14.0 & 15.5 & 18.4 & 36.3 \\
\hline 5 & 51.9 & 53.8 & 23.1 & 23.9 & 21.3 & 98.5 \\
\hline
\end{tabular}

(1) Pine 4 was harvested after the 1st period and replaced by another one with similar DBH and height, before the 2 nd period.

Sapwood depth was estimated with an allometric relationship derived from wood slices from 20 Aleppo pines from a close-by Aleppo pine forest (in Pefkochori, Chalkidiki; $39^{\circ} 58^{\prime} 26^{\prime \prime} \mathrm{N}, 23^{\circ} 36^{\prime} 34^{\prime \prime} \mathrm{E}$ ) as described in Fotelli et al. [41]. The equation best describing the relationship between sapwood area and diameter at breast height $(\mathrm{DBH})\left(\mathrm{R}^{2}=0.999\right.$, $p<0.05)$ was:

$$
\text { As }=0.077 \times \mathrm{DBH}^{1.9905}
$$

where As stands for sapwood area (in $\mathrm{m}^{2}$ ) and DBH for diameter at breast height (in $\mathrm{m}$ ). To verify this allometric equation for the studied forest stand, DBH and As were measured in additional eight (8) Aleppo pine trees from the study site, and the relationship between them was tested against the allometric relationship of Pefkochori. It was shown that the As values produced by the application of the two allometric equations were closely related $\left(\mathrm{R}^{2}=0.996, p<0.05 ;\right.$ Figure $\left.\mathrm{S} 1\right)$.

\subsection{Radial Profile Sap Flow Monitoring}

Xylem sap flux density was monitored at the five (5) Aleppo pines using the thermal dissipation method [42,43]. We installed on each of the five trees three Granier-type sensors at different sapwood depths, at 21,51 and $81 \mathrm{~mm}$. The $21 \mathrm{~mm}$ sapwood depth was selected as representative of the sapwood depth range most commonly used for sap flow measurements in forest trees, while the $51 \mathrm{~mm}$ and $81 \mathrm{~mm}$ sapwood depths were chosen for assessing sap flux patterns at greater depths. The studied Aleppo pines are characterized by high DBH, quite narrow heartwood, and deep sapwood (Table 1). Limited heartwood has similarly been reported in a study of $P$. canariensis [44]. Thus, we could safely assume that all sensors including the deeper ones at $81 \mathrm{~mm}$ were installed in conductive sapwood.

Both 51 and $81 \mathrm{~mm}$ sensors were developed using long gauge needles that were cut at the desirable length (51 $\mathrm{mm}$ and $81 \mathrm{~mm}$, accordingly). In these probes the thermocouple was placed at a distance $10 \mathrm{~mm}$ short of the total needle length and only $20 \mathrm{~mm}$ of the needle tip was covered with heating wire. Each sensor was radially inserted in the outer sapwood at breast height (DBH) after the bark was removed. The reference probe was inserted approximately $12.0 \mathrm{~cm}$ below the heated needle in a vertical alignment. All three sensors were installed at the same height with a $120^{\circ}$ distance among them. To exclude azimuthal effects, the three different depth sensors were established on the tree periphery the following way: the first $21 \mathrm{~mm}$ long sensor was installed on the north-facing side of Tree 1 and the $21 \mathrm{~mm}$ sensor on trees 2 to 5 was installed by moving by $75^{\circ}$ on each next tree's periphery, in a clockwise manner. The 51 and $81 \mathrm{~mm}$ sensors were installed then accordingly by maintaining the $120^{\circ}$ distance among them.

A CR10X datalogger connected to an AM 416 Multiplexer (CR10X Campbell Scientific, Logan, UT, USA) was used to heat the sensors and collect the probe outputs. The temperature difference between the Granier-type probes $(\Delta T)$ was recorded at $10 \mathrm{~s}$ intervals and data-logged as $15 \mathrm{~min}$ averages. $\Delta T$ values were related to the daily maximum temperature 
difference among the probes $(\Delta T m)$ to calculate sap flux density (Js, $\left.\mathrm{kg} \mathrm{m}^{-2} \mathrm{~h}^{-1}\right)$ according to Granier's equation [43]

$$
J s=428.4\left(\frac{\Delta T m-\Delta T}{\Delta T}\right)^{1.231}
$$

All probes and stems were insulated to minimize natural temperature gradients. Nevertheless, heating was disconnected in all sensors from 28 May 2019 to 6 June 2019 (10 days) to monitor the natural temperature gradients. Even though $\Delta T$ values were consistently $<5.4 \%$ of the sap flow signal, and corrections were not necessary [11], we modelled the measured natural temperature gradients using meteorological variables by means of principal components regression (PCR), for each individual sensor, to correct the temperature differences measured when the sensors were heated, as described by Graham [45] and Martínez-Vilalta et al. [46]. The corrected values were used to calculate sap flux density (Js) for the three different depths per tree $\left(\mathrm{kg} \mathrm{m}^{-2} \mathrm{~h}^{-1}\right)$. To scale-up to the sap flow per conducting sapwood area $\left(\mathrm{Qs} ; \mathrm{kg} \mathrm{h}^{-1}\right)$ a weighted mean was calculated according to Hatton et al. [47] and Poyatos et al. [13] as following:

$$
Q_{s}=J_{s, 21} A_{s, 21}+J_{s, 51} A_{s, 51}+J_{s, 81} A_{s, 81}+J_{s, 81} A_{s, i n}
$$

where $J_{s, i}$ is sap flux density at each measuring depth, $A_{s, i}$ is the corresponding annulus area and $A_{s, i n}$ is the conducting area beyond the influence of the last measuring point (deeper than $81 \mathrm{~mm}$ ).

\subsection{Data Analysis}

Data on temperature difference among the probes as well as meteorological data were curated in R [48] using the lubridate package [49]. Days with any missing values were excluded from analysis. Continuous missing days in 2008-2009 were due to malfunctions in the power supply. For the development of mean annual or seasonal diurnal curves of sap flux density (Js) and environmental parameters, as well as for the assessment of the seasonal variation of sap flow rates (Qs) and environmental parameters, 60-min means (1st period) and 30-min means (2nd period) were built from original 15-min data, in accordance to the frequency of datalogging of micrometeorological parameters. Then data were averaged on a DOY (Day of the year) basis of each measuring period for each tree $(n=5)$.

Statistical analysis and data visualization were performed with OriginPro, version 2020b (OriginLab Corp., Northampton, MA, USA) and IBM SPSS Statistics, version 23 (IBM Corp., Armonk, NY, USA). Relationships of Js and Qs with VPD, SWC, and solar radiation were tested with linear multiple stepwise regression and with non-linear regression for $p<0.05$. One way Anova and Tukey's test were used for detecting significant differences in sap flux density (Js) between the three sapwood depths and the different seasons at $p<0.05$. Values of March to May, June to August, September to November, and December to February were used for building the seasonal means of spring, summer, autumn, and winter, respectively. Significant differences between the daily curves of Js at the three sapwood depths were detected with the Wilcoxon and Kendall non-parametric tests at $p<0.05$.

\section{Results}

\subsection{Climate Uring the Study Periods}

Table 2 presents the long-term (2008-2019) and the annual and seasonal means of climatic traits of the forest stand during the two study periods. Overall, the wet period was characterized by substantially higher soil water content compared to the dry period. Rainfall and air temperature were also higher in the wet period, resulting in higher VPD values than in the dry period. Similarly, Tair and VPD were lower in the dry period, compared to the wet one, during each season. An exception was observed in regard to rainfall, which followed the same pattern in all seasons except from winter; then it was 
higher in the dry period than in the wet one. Finally, a pronounced difference was observed in SWC, which was quite lower in the summer and autumn of the dry period vs. the wet period.

Table 2. Means of air temperature (Tair), vapor pressure deficit (VPD), soil water content (SWC) and sum of rainfall at the forest stand during (a) the period 2008-2019, (b) the two study periods (Dry period: July 2008-November 2009, Wet period: April 2018-April 2020) and (c) the different seasons within each study period.

\begin{tabular}{ccccc}
\hline & Tair $\left({ }^{\circ} \mathbf{C}\right)$ & VPD $(\mathbf{K P a})$ & Rainfall $(\mathbf{m m})$ & SWC $(\mathbf{\%})$ \\
\hline 2008-2019 & 16.3 & 0.56 & 604.8 & $18.9^{\mathbf{( 1 )}}$ \\
\hline Dry period & 15.9 & 0.53 & 644.2 & 18.8 \\
\hline Spring & 14.1 & 0.42 & 115.8 & 24.7 \\
Summer & 24.3 & 0.96 & 105.0 & 13.5 \\
Autumn & 16.7 & 0.47 & 131.0 & 11.7 \\
Winter & 8.7 & 0.28 & 292.4 & 25.1 \\
\hline Wet period & 17.9 & 0.70 & 889.3 & 24.3 \\
\hline Spring & 17.0 & 0.54 & 171.0 & 23.2 \\
Summer & 26.0 & 1.21 & 260.1 & 21.8 \\
Autumn & 19.4 & 0.66 & 299.5 & 22.3 \\
Winter & 9.2 & 0.37 & 158.7 & 29.9 \\
\hline
\end{tabular}

(1) SWC was not recorded during July-August 2008 and March 2016-November 2017 due to malfunction.

\subsection{Diurnal and Seasonal Variation of Js with Increasing Sapwood Depth}

The diurnal curves of VPD and Js in the three sapwood depths on a seasonal basis are presented in Figure 1, while the seasonal means of Js are shown in Table 3 for the different sapwood depths and both study periods. The patterns and the range of Js differed when observed separately per season of the year and study period (dry vs. wet) (Figure 1).

Js at the outer sapwood $(21 \mathrm{~mm}$ ) was constantly higher than the other two depths, but the difference among depths was less pronounced in autumn, when in general the lowest Js values were recorded during both the dry and the wet period, despite the substantially higher VPD values in the latter case (Figure 1E,F, Table 3). In all other seasons, Js in $21 \mathrm{~mm}$ was significantly higher than in $81 \mathrm{~mm}$ in the dry period (Figure $1 \mathrm{~A}, \mathrm{C}, \mathrm{G}$ ) and significantly higher than both 51 and $81 \mathrm{~mm}$ in the wet period (Figure 1B,D,H). In both periods, the greater contribution of outer $(21 \mathrm{~mm})$ vs. inner xylem to sap flux was most pronounced in winter $(41.9 \%$ difference compared to Js in $81 \mathrm{~mm}$ in the dry period and $31.4 \%$ difference compared to Js in $51 \mathrm{~mm}$ in the wet season) (Table 3).

In the dry study period, differences in the peak of Js were recorded among the seasons. Js peaked later during the day in summer and spring than in autumn and winter. No such response was observed in the wet period (Figure 1).

During the dry period, the highest Js in all depths was recorded in spring, while in the wet period Js in all tested depths was in the same range during spring and summer (Figure 1A, Table 3), probably as a result of the high summer soil water availability and evaporative demand (high air temperature and VPD; Table 2). It is also noteworthy that although Js in all sapwood depths was restricted to a shorter day phase during the winter, still the peak values of winter Js in $21 \mathrm{~mm}$ were comparable to those of spring and summer, both during the dry and the wet period (Figure 1). 


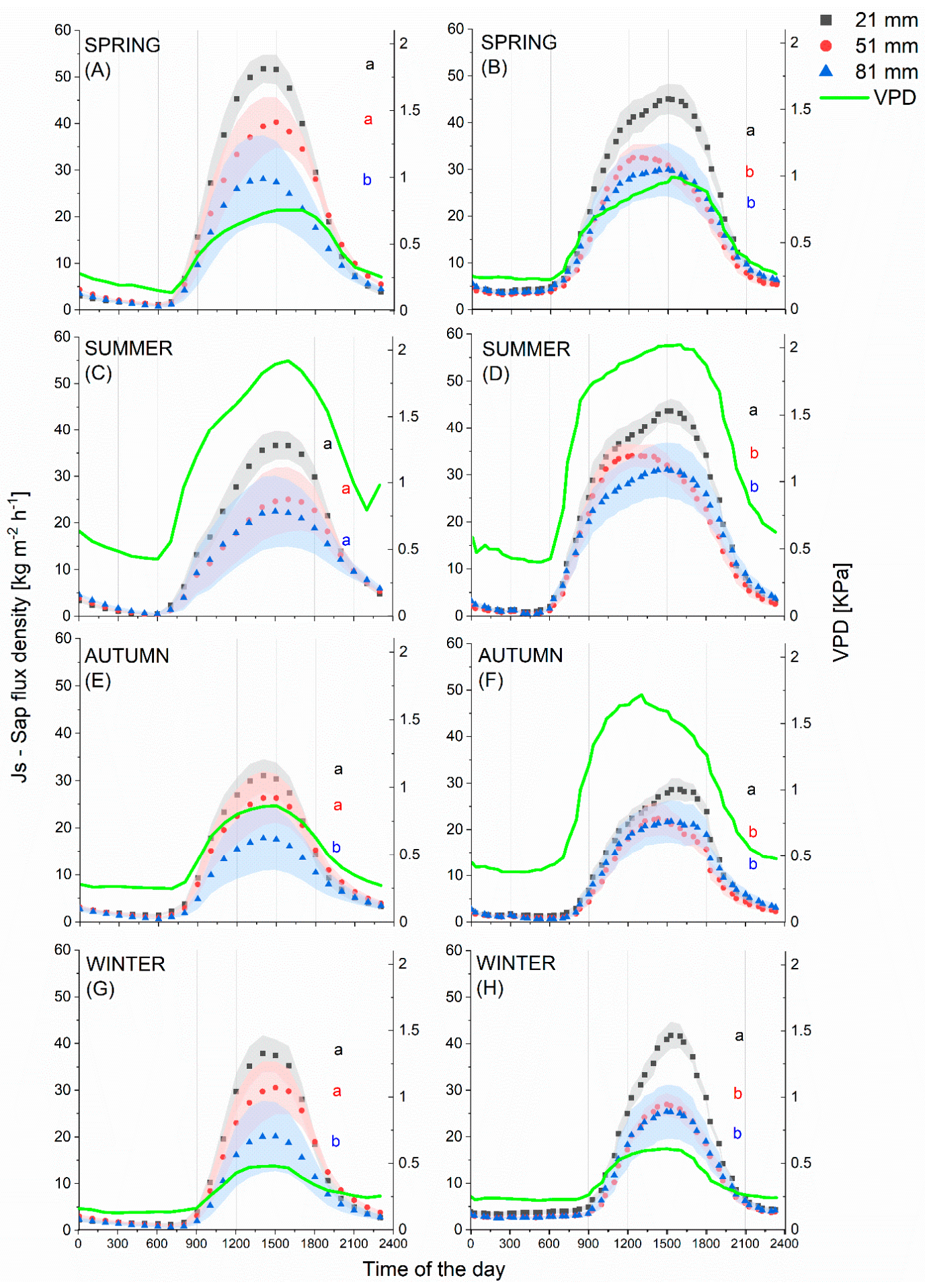

Figure 1. Diurnal variation of Js in the 3 radial depths and VPD in the different seasons of the year during the two study periods (dry period: A,C,E,G), wet period: B,D,F,H). Different letters indicate significant differences between the daily curves of Js in the 3 radial depths at $p<0.05$ within each season and period. Symbols represent mean values ( $n=5$ trees) and the shaded bands represent $\pm \mathrm{SE}$ of the means. 
Table 3. Mean diurnal Js \pm SE in the 3 different sapwood depths and in the different seasons during the two study periods (Dry period: July 2008-November 2009; wet period: April 2018-April 2020). The difference (\%) between Js at $21 \mathrm{~mm}$ and Js at the two inner depths is also shown. Lowercase different letters indicate significant differences between the 3 sapwood depths, within each season, while uppercase different letters indicate significant differences among the seasons.

\begin{tabular}{|c|c|c|c|c|c|}
\hline & \multicolumn{3}{|c|}{ Mean Js (kg m $\left.{ }^{-2} \mathrm{~h}^{-1}\right)$} & \multicolumn{2}{|c|}{$\begin{array}{c}\% \text { Difference of Js in } 21 \mathrm{~mm} \\
\text { Compared to }\end{array}$} \\
\hline & \multicolumn{5}{|c|}{ Dry Period } \\
\hline & Js $21 \mathrm{~mm}$ & Js $51 \mathrm{~mm}$ & Js $81 \mathrm{~mm}$ & Js $51 \mathrm{~mm}$ & Js $81 \mathrm{~mm}$ \\
\hline Spring & $19.4 \pm 4.0 a A$ & $16.3 \pm 2.9 a b A$ & $11.7 \pm 2.1 b A$ & 15.6 & 39.7 \\
\hline Summer & $13.4 \pm 2.8 a A B$ & $11.0 \pm 1.9 a B$ & $10.5 \pm 1.6 a A$ & 25.9 & 30.0 \\
\hline Autumn & $11.7 \pm 2.3 a B$ & $10.6 \pm 1.9 a B$ & $7.4 \pm 1.3 b B$ & 9.1 & 36.8 \\
\hline \multirow[t]{3}{*}{ Winter } & $12.5 \pm 2.8 a A B$ & $11.0 \pm 2.2 a B$ & $7.3 \pm 1.5 b B$ & 12.1 & 41.9 \\
\hline & \multicolumn{5}{|c|}{ Wet Period } \\
\hline & Js $21 \mathrm{~mm}$ & Js $51 \mathrm{~mm}$ & Js $81 \mathrm{~mm}$ & Js $51 \mathrm{~mm}$ & Js $81 \mathrm{~mm}$ \\
\hline Spring & $20.5 \pm 1.7 a A$ & $14.8 \pm 1.5 b A$ & $15.1 \pm 5.7 b A$ & 27.5 & 26.2 \\
\hline Summer & $19.2 \pm 1.6 a A$ & $15.2 \pm 1.6 b A$ & $15.0 \pm 6.0 \mathrm{bA}$ & 21.2 & 22.1 \\
\hline Autumn & $11.0 \pm 1.1 \mathrm{aC}$ & $8.3 \pm 1.3 b B$ & $9.1 \pm 4.6 a b B$ & 24.2 & 17.5 \\
\hline Winter & $14.6 \pm 1.0 a B$ & $10.0 \pm 0.9 b B$ & $10.1 \pm 5.8 a b B$ & 31.4 & 30.9 \\
\hline
\end{tabular}

The combined effect of VPD with solar radiation, or all climatic parameters, generally produced the strongest regression models describing the diurnal variation in Js during the seasons and the two study periods (Table S1). Among the tested climatic factors, VPD had the strongest control on the diurnal variation of Js in all sapwood depths $\left(R_{a d j}{ }^{2}\right.$ ranged from 0.802 to 0.990$)$. Furthermore, the effect of VPD tended to increase with increasing sapwood depth, but this pattern was not constant in all seasons. On the contrary, SWC had either the lowest or no effect on the diurnal variation of Js (Table S1).

Mean Js averaged over each study period, and its declining pattern with increasing sapwood depth is shown in Figure 2. In the dry period, Js was $13.9 \pm 1.2,11.6 \pm 2.4$, and $9.1 \pm 3.0 \mathrm{~kg} \mathrm{~m}^{-2} \mathrm{~h}^{-1}$ in 21,51, and $81 \mathrm{~mm}$ depth, respectively (Figure 2A), while in the wet period, the respective values were $16.6 \pm 1.1,12.2 \pm 1.2$, and $12.2 \pm 2.4 \mathrm{~kg} \mathrm{~m}^{-2} \mathrm{~h}^{-1}$ (Figure 2B). In general, Js was not affected by differences in $\mathrm{DBH}$ or its increment between the two study periods, apart from Js in $51 \mathrm{~mm}$, which increased with increasing DBH (Figure S3).

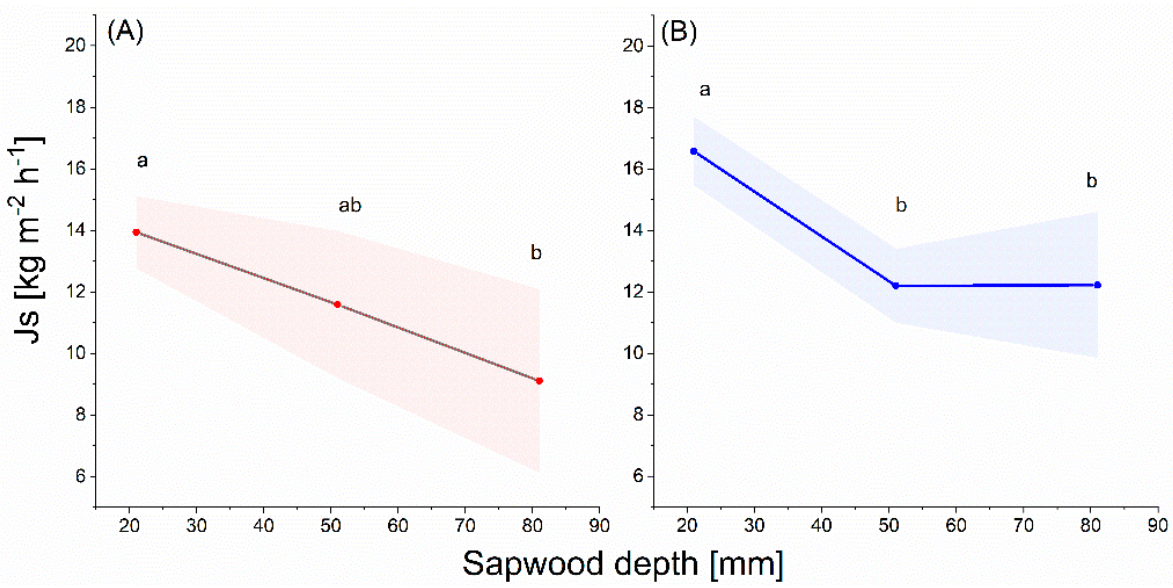

Figure 2. Variation of mean tree sap flux density (Js) with increasing radial sapwood depth during (A) the dry study period, and (B) the wet study period. Shaded bands represent \pm SE of the mean ( $n=5$ trees). Different letters indicate significant differences between the 3 sapwood depths. 


\subsection{Tree Sap Flow Rate on a Sapwood Area Basis (Qs) and Environmental Control on Qs}

In order to upscale the Js measurements to the tree level and calculate the sap flow on a sapwood area basis (Qs), a weighted mean was calculated according to Hatton et al. [47] and Poyatos et al. [13]. Considering solely Js measurements conducted at the outer sapwood $(21 \mathrm{~mm})$ than in different sapwood depths would result in an overestimation of Qs both in the dry period $(27.7 \pm 0.2 \%)$ and in the wet period $(20.2 \pm 0.4 \%)$.

For verification purposes, although we lacked information on Js in depths smaller than $21 \mathrm{~mm}$, we also calculated mean Js per tree with the Gaussian function proposed by Ford et al. [27] and Martínez-Vilalta et al. [46], as described in detail in Figure S2. Strong correlations between Qs values calculated both ways were found for both study periods $\left(R^{2}=0.99, p<0.05\right.$, Figure S2).

The seasonal fluctuation of Qs, SWC, and VPD during the year is presented in Figure 3 for both study periods. The substantially higher SWC and VPD levels of the wet period (Figure 3D) resulted in higher sap flow rates, particularly during the midsummer period (DOY 180-210).
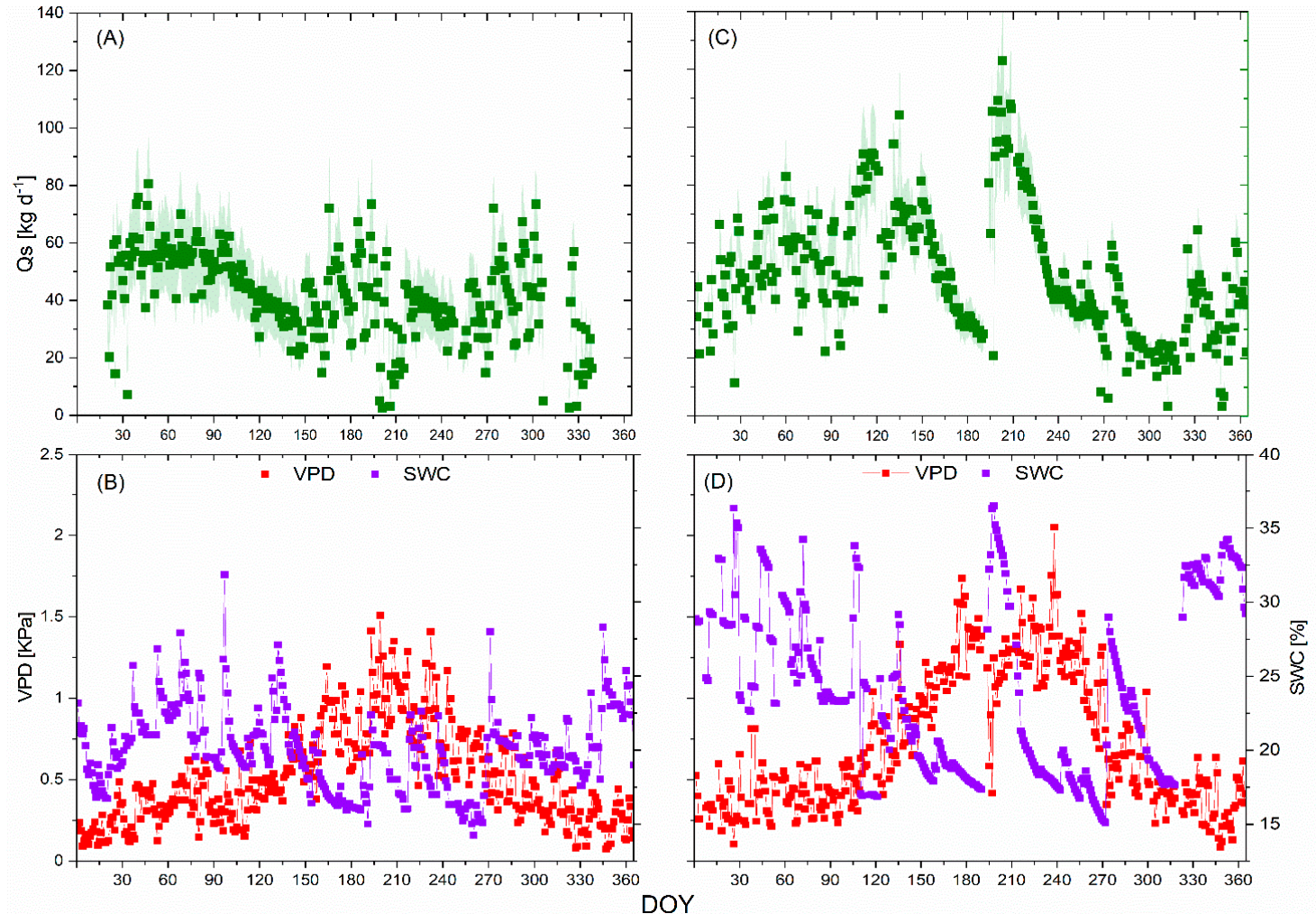

Figure 3. Seasonal variation of sap flow rate per sapwood area (Qs; $\left.\mathrm{kg} \mathrm{d}^{-1}\right)$, VPD, and SWC during the dry study period $(\mathbf{A}, \mathbf{B})$ and wet study period $(\mathbf{C}, \mathbf{D})$. In plots $(\mathbf{A}, \mathbf{C})$ symbols represent mean values of daily $Q$ s and shaded bands represent \pm SE $(n=5$ trees).

Among the tested relationships between environmental parameters (VPD, SWC, and solar radiation) and Qs only solar radiation had a significant effect when all days were considered simultaneously (Table S2). The effect of climate was also tested within different thresholds of VPD and SWC (data not shown), and it was found that additional and stronger climatic controls on Qs were detected when VPD and SWC were higher than $0.7 \mathrm{KPa}$ and $20 \%$, respectively (Table S2).

In particular, solar radiation largely controlled Qs when SWC was above $20 \%$, and this effect was stronger in the wet $\left(R^{2}\right.$ adj: $\left.0.579, p<0.001\right)$ than in the dry period $\left(R^{2}\right.$ adj: $0.220, p<0.001$ ) (Table S2) and better described by an allometric relationship (Figure $4 \mathrm{~A}, \mathrm{~B}$ ). 


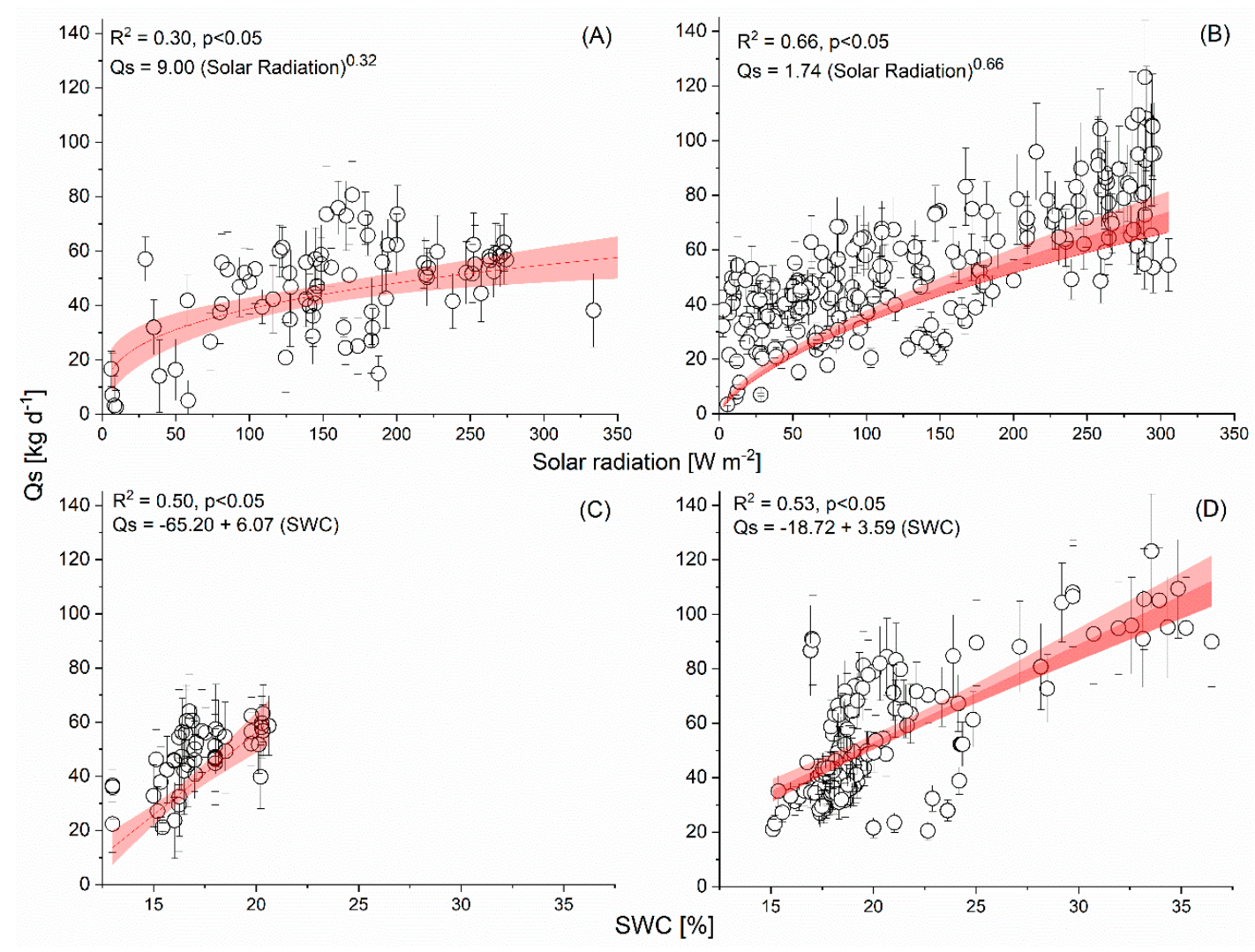

Figure 4. Relationships between Qs $\left[\mathrm{kg} \mathrm{d}^{-1}\right]$ and climatic parameters during the dry period (left) and the wet period (right) are shown by the regression models between Qs and solar radiation when SWC $>20 \%(\mathbf{A}, \mathbf{B})$ and SWC when VPD $>0.7 \mathrm{KPa}$ (C,D). Symbols indicate mean values, error bars indicate \pm SE ( $n=5$ trees) and shaded bands indicate confidence level of the regression models at $p<0.05$.

Furthermore, a strong influence of SWC on Qs was detected in days of high evaporative demand, when VPD was above $0.7 \mathrm{KPa}$ (Figure 4C,D). This effect of SWC was slightly higher in the wet period, than in the dry one, when combined with the effect of solar radiation $\left(\mathrm{R}_{\text {adj: }}^{2}\right.$ : 0.605, $p<0.001$; Table $\left.\mathrm{S} 2\right)$.

\section{Discussion}

In order to more accurately estimate the sap flow of adult Aleppo pines in a natural near-coastal forest in northern Greece, we assessed the radial variability of sap flux density (Js) during two periods (July 2008-November 2009 and April 2019-April 2020), differing in climatic conditions and predominantly in water availability. Three sapwood depths were used for this purpose; (a) $21 \mathrm{~mm}$ as the sapwood depth range most commonly used for sap flow measurements in forest trees (e.g., [41,50,51]) and (b) 51 and $81 \mathrm{~mm}$ as the studied pines are of high DBH and sapwood radius (Table 1). The latter sapwood depths were safely regarded as conductive and actively contributing to the trees' sap flow. Furthermore, the variation in both sap flux density (Js) and sap flow on a sapwood area basis (Qs) is discussed in relation to temporal and climatic variability, to enhance our understanding of Aleppo pine's water balance in eastern Mediterranean ecosystems.

\subsection{Sap Flux Density Changes with Increasing Sapwood Depth in Aleppo Pine}

Our results indicate a considerable change in Js with increasing sapwood depth, with the highest sap flux density occurring at the outer sapwood $(21 \mathrm{~mm})$ of the studied Aleppo pine trees during all seasons (Figures 1 and 2), in line with studies on other conifers $[29,30]$. A decreasing trend in Js was presented in deeper sapwood layers (51 and $81 \mathrm{~mm}$; Figures 1 and 2), which was more pronounced under drier conditions (1st study period) than under high water availability (2nd study period), when it remained stable 
after the depth of $51 \mathrm{~mm}$ (Figure 2). Similarly, Cohen et al. [35] observed an almost linear decrease of sap flux from c. 20 to $40 \mathrm{~mm}$ under quite arid conditions, in Aleppo pine stands in Israel. However, in this study [35], the only to our knowledge that dealt with the radial gradient of Js in P. halepensis, no sapwood depths greater than $44 \mathrm{~mm}$ were tested. Thus, no previous records are available on Js variability in Aleppo pine sapwood depths of $51 \mathrm{~mm}$ and $81 \mathrm{~mm}$ addressed in the present work.

Čermak and Nadezhdina [20], who examined the radial patterns of sap flow rate in five coniferous and four broad-leaved species also addressed the effect of water availability on the radial profile of sap flow. They found that undersaturated water conditions, xylem water content peaked at c. 20-30 mm sapwood depth, whereas under drought, it was maximized at 0-12 $\mathrm{mm}$ beneath the cambium. Moreover, Ganthaler et al. [52] observed in conifers that electrical resistivity increased in deeper sapwood areas, even more so as tree dehydration progressed. Such changes under different water availability conditions presumably explain the steeper radial Js patterns, we observed during the drier study period.

A linear decline in sap flux to even greater depths (from 20 to $90 \mathrm{~mm}$ ) was reported for Pinus brutia in Cyprus [30]. Consistently, in maritime pine Delzon et al. [22] reported a sharp decrease in sap flow with increasing sapwood depth in trees with $\mathrm{DBH}>42 \mathrm{~cm}$. Alvarado-Barrientos et al. [53] concluded that in Pinus patula in Mexico the peak of Js was recorded within the outermost $20-33 \%$ of sapwood. Similar declining patterns of sap flux density or specific conductivity of the xylem with increasing sapwood depth are reported for other conifers as well, suggesting that decreasing sap flux density in the inner sapwood of mature trees is associated with declining sapwood hydraulic conductivity, due to the presence of non-functional or blocked tracheids $[27,33,54,55]$.

Instead of a linear decrease with sapwood depth, others concluded that a curved radial profile is characterizing the sap flow pattern of conifers, which can be described by a Gaussian function $[18,27,29,46]$. In these cases, sap flux density increased gradually from directly below the cambium to $10-20 \mathrm{~mm}$ sapwood depth and decreased thereafter. However, no such pattern of radial profile in sap flow has been described in Aleppo pine [35] or in the closely related Brutian pine [30]. The lack of sap flow measurements at depths smaller than $20 \mathrm{~mm}$ in our study does not allow drawing any conclusions on a possible curved fit of sap flux radial profile in the studied Aleppo pines.

Nevertheless, independent of the pattern of sap flux decline with increasing sapwood depth, not taking into account the radial variability of sap flux density will result in a noticeable overestimation of sap flow rate at the tree level. In our case, if only Js at the outer sapwood would be considered, Qs of Aleppo pine would be overestimated by c. $27.7 \pm 0.2 \%$ under drier conditions and by c. $20.2 \pm 0.4 \%$ under higher water availability. Overestimations, based on the same rationale, were also estimated by other studies on conifers and ranged from 5.6\% [29] to 250\% [23], depending on temporal variation and climatic conditions.

\subsection{Short-and Long-Term Temporal Differences in Sap Flow Gradient in Relation to Climate}

During the dry period, Js peaked later in summer, compared to other seasons, probably in response to midday depression. Js diurnal fluctuation in outer sapwood $(21 \mathrm{~mm})$ and in the innermost sapwood $(81 \mathrm{~mm})$ were quite synchronized during the day in all seasons (Figure 1). Ford et al. [27] observed that water in inner sapwood is mobilized later in the day, when stem water gets depleted, despite possible high hydraulic resistance. In the dry period, Js in $51 \mathrm{~mm}$ responded in a similar way, but no such pattern was observed in the wet period for any of the deeper sapwood layers (Figure 1).

In the drier period, there was a clear gradient in sap flux density with increasing sapwood depth, particularly in spring and winter when the highest Js levels were recorded (Figure 1A,G). On the contrary, in the wet period, the contribution of outer xylem was clearly the highest, while the sapwood at $51 \mathrm{~mm}$ and $81 \mathrm{~mm}$ contributed almost equally to total sap flow in all seasons (Figure 1B,D,F,H). Similarly, Phillips et al. [33] and Nadezhdina 
et al. [26] reported that the outer xylem conducted considerably more water than the inner xylem under conditions associated with high Js values. Still, it cannot be overlooked that the outer sapwood had the highest sap flux densities, compared to inner sapwood, both under drier and wetter conditions (Figure 2), even during autumn when the lowest Js levels were recorded. However, the proportional contribution of Js at inner xylem to total sap flow increased during autumn (Table 3) in line with the conclusion of Ford et al. [27] that as the radial gradient becomes less steep, the inner xylem contributes more to total tree sap flow.

On a daily basis, the changes in the radial profile of Js in Aleppo pine were strongly controlled by the concurrent variation in VPD $\left(\mathrm{R}_{\mathrm{adj}}{ }^{2}=0.802-0.980\right.$ in all sapwood depths and seasons and in both study periods; Table S1). The relationship of Js to VPD tended to increase with increasing sapwood depth, but this pattern was not consistent in all seasons and study periods (Table S1). Cohen et al. [35] also reported a close control of VPD over sap flux in Aleppo pine, in accordance with studies in other conifers $[26,53,56]$. Such a determining role of VPD on Js during the day indicated that stomata optimized the time and extent of carbon uptake with respect to VPD, to maintain an optimal water balance. On the contrary, no effect of soil water content on the daily fluctuation of sap flux density was detected in any radial depth and season (Table S1), implying that Js responds rapidly to short-term changes in atmospheric water deficits, but not to soil water content, which is not modified as quickly during the day.

On an annual scale, Qs seemed to respond to variations in soil water content in both study periods (Figure 3), although the SWC of the dry period was substantially lower than of the wet period (Table 2), but no relationship between SWC and Qs could be established for the entire study periods (Table S2). The significant positive effect of SWC on Qs was detected only in days of high evaporative demand, when VPD was higher than $0.7 \mathrm{KPa}$ (Table S2, Figure 4C,D), contrary to the negative effect of rainfall and increased Tair on sap flux density of silver fir reported by Magh et al. [57]. In line with our results, SánchezCosta et al. [31] observed that the sap flow of Aleppo pine in Spain responded positively to increasing soil water only on days with VPD higher than $0.4 \mathrm{KPa}$.

The controlling role of SWC is highlighted by the fact that increasing solar radiation or the combined effect of increasing solar radiation and VPD led to enhanced Qs only at SWC $>20 \%$ (Figure $4 \mathrm{~A}, \mathrm{~B}$, Table S2), particularly during the wet period $\left(\mathrm{R}_{\mathrm{adj}}{ }^{2}=0.557\right.$, $p<0.001)$, thus when higher soil water availability allowed stomatal water loss in favor of assimilation. This response points to a limited control of solar radiation on Qs in drier days as stomatal control aimed at minimizing water losses. A decreased sensitivity of pines ecophysiological responses to other climatic factors at low soil moisture levels has previously been reported [56,58]. Tatarinov et al. [56] argued that changes in daily transpiration were strongly dominated by soil moisture availability. Moreover, they determined a similar threshold of SWC (22\%), above which increasing VPD could enhance sap flow, in a semi-arid Aleppo pine forest. Similarly, Chang et al. [29] observed a positive effect of solar radiation on sap flow only at higher, compared to lower, soil water content. The importance of adequate soil water (SWC > 20\%) for Qs under both drier and wetter conditions emphasizes the role of soil water availability in the studied Aleppo pine forest, possibly due to limited access to ground water. A compact $\mathrm{CaCO}_{3}$ layer observed at c. $50-150 \mathrm{~cm}$ soil depth at the study site, could potentially prohibit root penetration to greater depths [59].

Despite the complexity of environmental conditions within the forest stand and the difficulty in establishing firm relationships, there is a coordination of sap flow to climatic variability, and particularly to soil water availability, in the studied Aleppo pine forest.

\section{Conclusions}

We determined the radial variability in sap flux density of mature Aleppo pines with high DBH in a natural forest in northern Greece during two periods with different water availability. In both study periods, the contribution of outer xylem was the highest. A linear decline in sap flux density with increasing xylem depth was evident during the dry period. 
In the wet period, sap flux density decreased in $51 \mathrm{~mm}$ sapwood depth but remained stable in inner depth. These patterns of Js radial profile were, with some variations, present in all seasons of the year. We also estimated that not taking into account the radial variability of sap flux density when aiming at upscaling to sap flow on a tree level, would lead to an overestimation of c. 20.2-27.7\%, under varying soil water availability. Furthermore, our results support that temporal variations in the radial profile of Js and in sap flow rates in the studied Aleppo pine forest are associated with dynamic environmental changes. On a diurnal basis, VPD was the strongest determinant of sap flux density in all sapwood depths and in both study periods, pointing to a close stomatal regulation to short-term changes in evaporative demand, while on a larger temporal scale, SWC controlled the effects of other environmental parameters. Only when SWC was high enough (>20\%) did sap flow respond positively to increasing solar radiation and VPD, indicating the decisive role of soil water availability in the studied ecosystem. These findings can broaden our knowledge on the water balance strategies of Aleppo pine, at its eastern distribution in the Mediterranean basin, where information is limited to date to regions that are more arid.

Supplementary Materials: The following are available online at https: / /www.mdpi.com/1999-4 $907 / 12 / 1 / 2 /$ s1, Figure S1: Linear relationship between the sapwood depths of the five (5) studied trees, calculated with the two allometric equations developed from Aleppo pine trees at Pefkochori and Sani, Chalkidiki, Greece. The shaded band represents the confidence level of the regression fit at $p<0.001$, Figure S2: Relationship between the sap flow rates on a sapwood area basis calculated as weighted means $[13,47](\mathrm{Qs}, \mathrm{M})$ of the 3 sapwood depths and by the Gaussian equation $(\mathrm{Qs}, \mathrm{G})$ of Ford et al. [27] and Martínez-Vilalta et al. [46] for the dry (A) and the wet (B) period, Figure S3: Relationship between sap flux density (Js) at the three studied sapwood depths and diameter at breast height (DBH). Symbols represent mean values of Js, averaged per DOY and tree $(n=365)$, corresponding to the $\mathrm{DBH}$ of the studied Aleppo pines during the two study periods (Dry period: 1 July 2008-30 November 2009; Wet period: 13 April 2018-13 April 2020). The regression line indicates the significant relationship between Js and DBH which was found only for Js at $51 \mathrm{~mm}$ sapwood depth, Table S1: Multiple stepwise regression analysis of the relationships between the diurnal variation of sap flux density (Js) at the 3 sapwood depths (21, 51 and $81 \mathrm{~mm}$ ) and climatic parameters (vapor pressure deficit-VPD, soil water content-SWC and solar radiation-Rad) during the different seasons (spring, summer, autumn, winter) of the two study periods (Dry period: 1 July 2008-30 November 2009; Wet period: 13 April 2018-13 April 2020). The adjusted $R^{2}$ and $p$ level of each regression model are presented. The models with the highest $\mathrm{R}^{2}$ and significance level are indicated with bold, while non-significant models are indicated with n.s., Table S2: Multiple stepwise regression analysis of the relationships between mean weighted sap flow on a sapwood area basis (Qs) and climatic parameters (vapor pressure deficit-VPD, soil water content-SWC and solar radiation-Rad) during the two study periods (Dry period: 1 July 2008-30 November 2009; Wet period: 13 April 2018-13 April 2020). Regression models were tested including all days of each study period (whole period), only days with VPD $>0.7 \mathrm{KPa}$ or only days with $\mathrm{SWC}>20 \%$. The adjusted $\mathrm{R}^{2}$ and $p$ level of each regression model are presented. The models with the highest $R^{2}$ and significance level are indicated with bold, while non-significant models are indicated with n.s.

Author Contributions: Conceptualization, M.N.F.; methodology, E.K. and M.N.F.; formal analysis, E.K. and M.N.F.; investigation, M.N.F.; resources, M.N.F.; data curation, E.K. and M.N.F.; writingoriginal draft preparation, E.K.; writing-review and editing, M.N.F.; visualization, M.N.F. Both authors have read and agreed to the published version of the manuscript.

Funding: This research received no external funding.

Institutional Review Board Statement: Not applicable.

Informed Consent Statement: Not applicable.

Data Availability Statement: The data presented in this study are available from the corresponding author upon reasonable request. 
Acknowledgments: N. Fyllas, Aegean University, is kindly acknowledged for his assistance on data curation with R. We also wish to thank G. Spyroglou for the biometrical characterization of the studied trees and M. Dimitriou for his precious technical support during sap flow sensors preparation and installation. We are grateful to K. Radoglou, Democritus University of Thrace, and Sani Resort S.A. for the provision of datalogging and power supply infrastructure at the study site. The authors wish to thank the anonymous reviewer for the helpful comments and suggestions during the revision stage.

Conflicts of Interest: The authors declare no conflict of interest.

\section{References}

1. Granier, A.; Huc, R.; Barigah, S. Transpiration of natural rain forest and its dependence on climatic factors. Agric. For. Meteorol. 1996, 78, 19-29. [CrossRef]

2. Biron, P.; Siegwolf, R.; Granier, A. Estimates of water vapor flux and canopy conductance of Scots pine at the tree level utilizing different xylem sap flow methods. Theor. Appl. Clim. 1996, 53, 105-113. [CrossRef]

3. Pataki, D.E.; Oren, R.; Phillips, N. Responses of sap flux and stomatal conductance of Pinus taeda L. trees to stepwise reductions in leaf area. J. Exp. Bot. 1998, 49, 871-878. [CrossRef]

4. Tsuruta, K.; Komatsu, H.; Kume, T.; Shinohara, Y.; Otsuki, K. Canopy transpiration in two Japanese cypress forests with contrasting structures. J. For. Res. 2015, 20, 464-474. [CrossRef]

5. $\quad$ Oren, R.; Phillips, N.; Ewers, B.E.; Pataki, D.E.; Megonigal, J.P. Sap-flux-scaled transpiration responses to light, vapor pressure deficit, and leaf area reduction in a flooded Taxodium distichum forest. Tree Physiol. 1999, 19, 337-347. [CrossRef]

6. Ryan, M.G.; Bond, B.J.; Law, B.E.; Hubbard, R.M.; Woodruff, D.; Cienciala, E.; Kucera, J. Transpiration and whole-tree conductance in ponderosa pine trees of different heights. Oecologia 2000, 124, 553-560. [CrossRef]

7. Köstner, B.M.M.; Schulze, E.-D.; Kelliher, F.M.; Hollinger, D.Y.; Byers, J.N.; Hunt, J.E.; McSeveny, T.M.; Meserth, R.; Weir, P.L. Transpiration and canopy conductance in a pristine broad-leaved forest of Nothofagus: An analysis of xylem sap flow and eddy correlation measurements. Oecologia 1992, 91, 350-359. [CrossRef]

8. Granier, A.; Loustau, D. Measuring and modelling the transpiration of a maritime pine canopy from sap-flow data. Agric. For. Meteorol. 1994, 71, 61-81. [CrossRef]

9. Oren, R.; Phillips, N.G.; Katul, G.; Ewers, B.E.; Pataki, D.E. Scaling xylem sap flux and soil water balance and calculating variance: A method for partitioning water flux in forests. Annal. Sci. For. 1998, 55, 191-216. [CrossRef]

10. Ducrey, M.; Duhoux, F.; Huc, R.; Rigolot, E. The ecophysiological and growth responses of Aleppo pine (Pinushalepensis) to controlled heating applied to the base of the trunk. Can. J. For. Res. 1996, 26, 1366-1374. [CrossRef]

11. Do, F.; Rocheteau, A. Influence of natural temperature gradients on measurements of xylem sap flow with thermal dissipation probes. 2. Advantages and calibration of a noncontinuous heating system. Tree Physiol. 2002, 22, 649-654. [CrossRef] [PubMed]

12. Martínez-Vilalta, J.; Mangirón, M.; Ogaya, R.; Sauret, M.; Serrano, L.; Peñuelas, J.; Piñol, J. Sap flow of three co-occurring Mediterranean woody species under varying atmospheric and soil water conditions. Tree Physiol. 2003, 23, 747-758. [CrossRef] [PubMed]

13. Poyatos, R.; Llorens, P.; Gallart, F. Transpiration of montane Pinus sylvestris L. and Quercus pubescens Willd. forest stands measured with sap flow sensors in NE Spain. Hydrol. Earth Syst. Sci. Discuss. 2005, 2, 1011-1046. [CrossRef]

14. Renninger, H.J.; Clark, K.L.; Skowronski, N.S.; Schäfer, K.V.R. Effects of a prescribed fire on water use and photosynthetic capacity of pitch pines. Trees 2013, 27, 1115-1127. [CrossRef]

15. Sánchez-Costa, E.; Sabaté, S.; Poyatos, R. Identifying water use strategies in mediterranean tree species combining sap flow and dendrometer data. Acta Hortic. 2013, 269-275. [CrossRef]

16. Mitchell, P.J.; O'Grady, A.P.; Tissue, D.T.; Worledge, D.; Pinkard, E.A. Co-ordination of growth, gas exchange and hydraulics define the carbon safety margin in tree species with contrasting drought strategies. Tree Physiol. 2014, 34, 443-458. [CrossRef]

17. Zhu, L.; Wang, Q.; Ni, G.; Niu, J.; Zhao, P.; Zhang, Z.; Zhao, P.; Gao, J.; Huang, Y.; Gu, D.; et al. Stomatal and hydraulic conductance and water use in a eucalypt plantation in Guangxi, southern China. Agric. For. Meteorol. 2015, 202, 61-68. [CrossRef]

18. Berdanier, A.B.; Miniat, C.F.; Clark, J.S. Predictive models for radial sap flux variation in coniferous, diffuse-porous and ring-porous temperate trees. Tree Physiol. 2016, 36, 932-941. [CrossRef]

19. Čermák, J.; Cienciala, E.; Kučera, J.; Hällgren, J.-E. Radial velocity profiles of water flow in trunks of Norway spruce and oak and the response of spruce to severing. Tree Physiol. 1992, 10, 367-380. [CrossRef]

20. Čermák, J.; Nadezhdina, N. Sapwood as the scaling parameter- defining according to xylem water content or radial pattern of sap flow? Annal. Sci. For. 1998, 55, 509-521. [CrossRef]

21. Lu, P.; Müller, W.J.; Chacko, E.K. Spatial variations in xylem sap flux density in the trunk of orchard-grown, mature mango trees under changing soil water conditions. Tree Physiol. 2000, 20, 683-692. [CrossRef]

22. Delzon, S.; Sartore, M.; Granier, A.; Loustau, D. Radial profiles of sap flow with increasing tree size in maritime pine. Tree Physiol. 2004, 24, 1285-1293. [CrossRef] [PubMed]

23. Fiora, A.; Cescatti, A. Diurnal and seasonal variability in radial distribution of sap flux density: Implications for estimating stand transpiration. Tree Physiol. 2006, 26, 1217-1225. [CrossRef] [PubMed] 
24. Reyes-Acosta, J.L.; Lubczynski, M.W. Optimization of dry-season sap flow measurements in an oak semi-arid open woodland in Spain. Ecohydrology 2012, 7, 258-277. [CrossRef]

25. Zhang, J.-G.; He, Q.-Y.; Shi, W.-Y.; Otsuki, K.; Yamanaka, N.; Du, S.; Du, S. Radial variations in xylem sap flow and their effect on whole-tree water use estimates. Hydrol. Process. 2015, 29, 4993-5002. [CrossRef]

26. Nadezhdina, N.; Cermák, J.; Ceulemans, R.J. Radial patterns of sap flow in woody stems of dominant and understory species: Scaling errors associated with positioning of sensors. Tree Physiol. 2002, 22, 907-918. [CrossRef]

27. Ford, C.R.; McGuire, M.A.; Mitchell, R.J.; Teskey, R.O. Assessing variation in the radial profile of sap flux density in Pinus species and its effect on daily water use. Tree Physiol. 2004, 24, 241-249. [CrossRef]

28. Krauss, K.W.; Duberstein, J.A. Sapflow and water use of freshwater wetland trees exposed to saltwater incursion in a tidally influenced South Carolina watershed. Can. J. For. Res. 2010, 40, 525-535. [CrossRef]

29. Chang, X.; Zhao, W.; He, Z. Radial pattern of sap flow and response to microclimate and soil moisture in Qinghai spruce (Picea crassifolia) in the upper Heihe River Basin of arid northwestern China. Agric. For. Meteorol. 2014, 187, 14-21. [CrossRef]

30. Eliades, M.; Bruggeman, A.; Djuma, H.; Lubczynski, M.W. Tree Water Dynamics in a Semi-Arid, Pinus brutia Forest. Water 2018, 10, 1039. [CrossRef]

31. Sánchez-Costa, E.; Poyatos, R.; Sabaté, S. Contrasting growth and water use strategies in four co-occurring Mediterranean tree species revealed by concurrent measurements of sap flow and stem diameter variations. Agric. For. Meteorol. 2015, 207, 24-37. [CrossRef]

32. Bush, S.; Hultine, K.R.; Sperry, J.S.; Ehleringer, J.R. Calibration of thermal dissipation sap flow probes for ring- and diffuse-porous trees. Tree Physiol. 2010, 30, 1545-1554. [CrossRef]

33. Phillips, N.; Oren, R.; Zimmermann, R. Radial patterns of xylem sap flow in non-, diffuse- and ring-porous tree species. Plant. Cell Environ. 1996, 19, 983-990. [CrossRef]

34. Hernandez-Santana, V.; Fernández, J.; Rodriguez-Dominguez, C.; Romero, R.; Diaz-Espejo, A. The dynamics of radial sap flux density reflects changes in stomatal conductance in response to soil and air water deficit. Agric. For. Meteorol. 2016, 2016, 92-101. [CrossRef]

35. Cohen, Y.; Cohen, S.; Cantuarias-Avilés, T.; Schiller, G. Variations in the radial gradient of sap velocity in trunks of forest and fruit trees. Plant. Soil 2007, 305, 49-59. [CrossRef]

36. Euro+Med (2006+). Euro+Med PlantBase-The Information Resource for Euro-Mediterranean Plant Diversity. Available online: http:/ / ww2.bgbm.org/EuroPlusMed/ (accessed on 20 June 2020).

37. Chambel, R.; Climent, J.; Pichot, C.; Ducci, F. Mediterranean Pines (Pinus halepensis Mill. and brutia Ten.). In Managing Forest Ecosystems; Springer Science and Business Media LLC: Berlin, Germany, 2013; Volume 25, pp. $229-265$.

38. García-Ruiz, J.M.; López-Moreno, J.I.; Vicente-Serrano, S.M.; Lasanta-Martínez, T.; Beguería, S. Mediterranean water resources in a global change scenario. Earth-Sci. Rev. 2011, 105, 121-139. [CrossRef]

39. Sarris, D.; Christodoulakis, D.; Körner, C. Recent decline in precipitation and tree growth in the eastern Mediterranean. Glob. Chang. Biol. 2007, 13, 1187-1200. [CrossRef]

40. Schiller, G.; Cohen, Y. Water regime of a pine forest under a Mediterranean climate. Agric. For. Meteorol. 1995, 74, 181-193. [CrossRef]

41. Fotelli, M.; Korakaki, E.; Paparrizos, S.; Radoglou, K.; Awada, T.; Matzarakis, A. Environmental Controls on the Seasonal Variation in Gas Exchange and Water Balance in a Near-Coastal Mediterranean Pinus halepensis Forest. Forests 2019, 10, 313. [CrossRef]

42. Granier, A. A new method of sap flow measurement in tree stems. Ann. Sci. For. 1985, 42, 193-200. [CrossRef]

43. Granier, A. Evaluation of transpiration in a Douglas-fir stand by means of sap flow measurements. Tree Physiol. 1987, 3, 309-320. [CrossRef] [PubMed]

44. Climent, J.; Gil, L.; Pardos, J. Heartwood and sapwood development and its relationship to growth and environment in Pinus canariensis Chr.Sm ex DC. For. Ecol. Manage. 1993, 59, 165-174. [CrossRef]

45. Graham, M.H. confronting multicollinearity in ecological multiple regression. Ecology 2003, 84, 2809-2815. [CrossRef]

46. Martínez-Vilalta, J.; Vanderklein, D.; Mencuccini, M. Tree height and age-related decline in growth in Scots pine (Pinus sylvestris L.). Oecologia 2006, 150, 529-544. [CrossRef]

47. Hatton, T.J.; Catchpole, E.A.; Vertessy, R.A. Integration of sapflow velocity to estimate plant water use. Tree Physiol. 1990, 6, 201-209. [CrossRef]

48. R Core Team. R: A Language and Environment for Statistical Computing; R Foundation for Statistical Computing: Vienna, Austria, 2019.

49. Grolemund, G.; Wickham, H. Dates and Times Made Easy with lubridate. J. Stat. Softw. 2011, 40, 1-25. [CrossRef]

50. Awada, T.; El-Hage, R.; Geha, M.; Wedin, D.A.; Huddle, J.A.; Zhou, X.; Msanne, J.; Sudmeyer, R.A.; Martin, D.L.; Brandle, J.R. Intra-annual variability and environmental controls over transpiration in a 58-year-old even-aged stand of invasive woodyJuniperus virginianaL. in the Nebraska Sandhills, USA. Ecohydrology 2012, 6, 731-740. [CrossRef]

51. Wang, Q.; Lintunen, A.; Zhao, P.; Shen, W.; Salmon, Y.; Chen, X.; Ouyang, L.; Zhu, L.; Ni, G.-Y.; Sun, D.; et al. Assessing Environmental Control of Sap Flux of Three Tree Species Plantations in Degraded Hilly Lands in South China. Forests 2020, 11, 206. [CrossRef]

52. Ganthaler, A.; Sailer, J.; Bär, A.; Losso, A.; Mayr, S. Noninvasive Analysis of Tree Stems by Electrical Resistivity Tomography: Unraveling the Effects of Temperature, Water Status, and Electrode Installation. Front. Plant. Sci. 2019, 10. [CrossRef]

53. Alvarado-Barrientos, M.S.; Hernandez-Santana, V.; Asbjornsen, H. Variability of the radial profile of sap velocity in Pinus patula from contrasting stands within the seasonal cloud forest zone of Veracruz, Mexico. Agric. For. Meteorol. 2013, 168, 108-119. [CrossRef] 
54. Sperry, J.S.; Perry, A.H.; Sullivan, J.E.M. Pit Membrane Degradation and Air-Embolism Formation in Ageing Xylem Vessels ofPopulus tremuloidesMichx. J. Exp. Bot. 1991, 42, 1399-1406. [CrossRef]

55. Spicer, R.; Gartner, B. The effects of cambial age and position within the stem on specific conductivity in Douglas-fir (Pseudotsuga menziesii) sapwood. Trees 2001, 15, 222-229. [CrossRef]

56. Tatarinov, F.; Rotenberg, E.; Maseyk, K.; Ogée, J.; Klein, T.; Yakir, D. Resilience to seasonal heat wave episodes in a Mediterranean pine forest. New Phytol. 2016, 210, 485-496. [CrossRef] [PubMed]

57. Magh, R.-K.; Bonn, B.; Grote, R.; Burzlaff, T.; Pfautsch, S.; Rennenberg, H. Drought Superimposes the Positive Effect of Silver Fir on Water Relations of European Beech in Mature Forest Stands. Forests 2019, 10, 897. [CrossRef]

58. Addington, R.N.; Mitchell, R.J.; Oren, R.; Donovan, L.A. Stomatal sensitivity to vapor pressure deficit and its relationship to hydraulic conductance in Pinus palustris. Tree Physiol. 2004, 24, 561-569. [CrossRef] [PubMed]

59. Orfanoudakis, M.; Democritus University of Thrace, Nea Orestiada, Greece. Personal Communication, 2020. 